\title{
A SHORT DISCOURSE ON THE QUESTION OF RATIFICATION OF THE UNITED NATIONS HUMAN RIGHTS TREATIES : OPTION OR OBLIGATION? *
}

[Contribution made at the Constitutional Law Round Table of the 1968 Annual Meeting of the Association of American Law Schools in New Orleans, the subject debated being whether or not «the United States Senate be urged to ratify the Human Rights Treaties and the Genocide Convention»]

Prof. Dr. Münci KAPANI

\section{Mr. Chairman,}

Speaking as an outsider, I wonder whether I am at an advantage or a disadvantage when it comes to expressing my views on what appears to be a controversial matter of United States' internal policy. I will not hesitate, however, to declare myself unconditionally in favour of the ratification of the Human Rights Treaties by the United States Senate.

It is not my intention to dwell upon the constitutional technicalities raised by Mr. Deutsch in support of the negative case. I must confess that I have had some difficulty in following his arguments, although it is apparent that he was mainly concerned with

(*) Bu yazı, Prof, Münci Kapani'nin davetli olarak katıldığı Amerikan Hukuk Fakülteleri Birliği'nin (Association of American Law Schools) 1968 Arallk ayında New Orleans'daki Yıllık Kongresinde düzenlenen Yuvarlak Masa Toplantılarından birinde yapmış olduğu konușmanın metnidir. Tartışılan konu, Birleşmiş Milletler Genel Kurulunca kabul edilen ve bütün devletlerin imzalarına açık tutulan Insan Hakları Sözleşmeleri ve özellikle Amerika Birleșik Devletleri Senatosunun bu Sözleşmeleri onaylayıp onaylamaması idi. Prof. Kapani konuşmasında, demokrasi ve insan hakları ilkelerine bağlı olma iddiasında bulunan bütün devletler - ve bu arada Amerika Birleşik Devletleri - için adı geçen Sözleşmelere katılmanın kaçınılmaz bir ödev olduğu görüş̧ünü savunmuştur. Prof. Kapani ayrıca, zengin ve gelişmiş ülkelerin sadece bu Sözleşmelere katılmakla yetinemiyeceklerini, insan haklarını dünya ölçüsünde geçerli kılmak ve gerçekten «evrenselleştirmek» konusunda 
the treaty-making power of the Federal Government and the possible encroachment upon the powers reserved to the States by the Constitution as a consequence of the ratification of the Human Rights Traaties by the United States Senate. My only comment on this point will be this: It is difficult to conceive that adherence by a Federal Government -whatever the peculiarities of its federal system - to an international treaty spelling out the fundamental rights and freedoms of all human beings could constitute an "invasion" of the domestic jurisdiction of the State governments, unless it is the law or recognised custom of any particular State or States to disregard and violate these fundamental rights and freedoms. This point becomes somewhat more poignant if the treaty in question is one which aims at nothing but the prevention and punishment of the crime of Genocide. Quite evidently, we cannot hold much hope for the future of U. N. sponsored multi-lateral agreements if the constitutional lawyers and politicians in all the countries concerned are to maintain the same conservative and restrictive approach to the treaty-making power of their respective goveruments.

However, it is comforting to note that in this country many leading publicists strongly support the participation of the United States in the United Nations Human Rights Programs, effectively arguing that there are no constitutional barriers to such participation. Professor Carl J. Friedrich, for example, is of the opinion that "states' rights cannot be pleaded against human rights within a federal system, except where the constitution explicitly permits local diversity. In case of doubt, the presumption must be in favor of the human right, because in the United States man is considered more important than the state» (See his Rights, Liberties, Freedoms: A Reapprai.sal, in the American Political Sciences Review, Vol. LVII. No. 4). For their part, Professors Myres S. McDougal and Gertrude C. K. Leighton seem even more categorical in asserting that "(our) participation is well within the scope of the treaty and other federal powej"». After elaborating this point at great length and convin-

kencilerine özel bir görev düştüğünü de belirtmiştir. Konuşmacı, yoksul iilkelerde yaşayan geniş insan yığınlarını hiç değilse en ilkel «insan hakları»na kavuşturabilmek bakımından șimdiye kadar yapılmakta olan ekoromik yardımların yeterli olmadı̆̆ını, bunun çoğu zaman yardımı yapen ïlkenin kendi sanayici ve ihracatçlarına verilen dolaylı bir sübvansyon niteliği taşıdığını, bundan böyle milletlerarası alanda gerçek anlamıla yeni bir "yardım» kavramının benimsenmesinin şart olduğนnu ve bunun da tamamen karşılıksız bir yardım olması gerektiğini açıklamıştır. 
cingly refuting every argument put forward by those opposed to the idea of participation, Professors McDougal and Leighton conclude by stating that the negative case "misconceives the intimate interdependences, if not identity, of human rights and security, the worldwide interdependences of peoples elsewhere; misconceives our obligations under the United Nations Charter...; misconceives both the scope of federal power under our Constitution over matters of international concern and the safeguard imposed by the Constitution on the exercise of such power; and, finally, misconceives the indispensability of human rights protection to a free society...» (See their joint article, The Rights of Man in the World Community: Constitutional Illusions versus Rational Action, in Studies in World Public Order, by Myres S. McDougal and Associates. Yale University Press, 1960).

Having quoted these authoritative opinions concerning the position of the United States, I should now like to look at this issue from a broader perspective, even at the risk of somewhat extending the formal scope of the present debate. Viewed from an idealistic angle, concern over domestic jurisdictional niceties is indeed very much dwarfed by the magnitude of international and moral obligations which devolve on all countries who profess attachment to democratic and liberal values. So far, as we all know, although a great deal of lip service has been paid to the ideal of human rights, extremely little has been done to implement it. In this International Year of Human Rights, now drawing to its close, there is very little cause for self-congratulation when one considers that some of the basic rights set out in the Universal Declaration of 1948 are being repeatedly trampled upon or completely denied. An honest stock-taking of the situation at this juncture would certainly justify the deep disillusionment felt by responsible people throughout the world.

But now, when at long last the General Assembly of the United Nations has adopted the International Covenants on Civil and Political Rights, and on Economic, Social and Cultural Rights, there is renewed hope of securing an international guarantee of human rights and fundamental freedoms. It is stipulated that these Covenants can come into force only after 35 State Members of the United Nations have ratified them.

Here, quite clearly, an inescapable choice awaits the United States. Can she really continue to sit back endlessly debating and wavering on the question of ratification, leaving the rest of the world 
puzzled over her lack of a positive stand? Or should she be among the first nations to ratify these treaties, thus encouraging other countries to follow suit and giving at the same time tangible proof of the sircerity of her claim to be a champion of democratic freedoms? Surely the second course is the obvious one, both from the point of view of moral considerations as well as from that of practical politics of self-interest regarding world image and prestige.

At this point, going beyond the question of ratification, I would like to submit the view that the United States should not content herself with mere adherence to the Human Rights Treaties which, after all, does not require any great sacrifice - but should take an active leading role in making the concept of human rights a concrete reality on a universel scale. Today we live in a world tragically divided into "haves» and «have-nots», one third of its populaticn enjoying a life of ease and comfort while the remaining two thirds exist under conditions of indescribable hardship and misery. For the great majority of these wretched masses the term «human rights» is meaningless, for they are deprived of even the most elementary rights of every human being. Indeed, their very existence is precarious, constantly threatened by hunger and disease. This is the shame and the tragedy of our century and it can no longer be ignored.

The International Conference on Human Rights held in Teheran earlier this year concentrated its attention on this problem, and, in calling for individual national effort to bridge the chasm between the rich and poor nations it exempted no nation from the obligation to contribute. The Proclamation of Teheran stated that contributions should be made according to each nation's capacity.

Now, the United States may claim that, as the richest country in the world, she already bears the main burden of economic aid to the underdeveloped countries. But I think the time has come to adopt a new definition of «aid". All aid given to the poor nations should be, in order to merit the name, completely interest-free and untied - with no strings attached. In other words, it should be genuine, unselfish, altruistic aid and not, as has so often been the case, a disguised subsidy to domestic industrialists in the export business. The use of the word «altruistic» in this context may sound a bit naive, especially to those who believe in the truth of Bismarck's :amous aphorism which asserts, quite bluntly, that «there is no alt:uism among nations». But this dictum should no longer 
be valid in our day. Men of goodwill, the defenders of a new international morality, should see to it that it will no longer be valid.

I must ask your indulgence for this slight digression which may not appear to be directly relevant to the subject under discussion, but in my opinion all questions concerning the implementation of human rights should be assessed in this broader perspective, lest they may not be fully understood and grasped in their proper dimensions.

I should like to conclude by saying that ratification of the U. N. sponsored Human Rights Treaties constitutes a moral as well as rational obligation for the United States and all the other democratic countries of the free world. Failure to adhere to these Treaties by any government which professes verbal attachment to liberal values would be automatically branded as nothing less than sheer hypocrisy by world public opinion, no matter how hard it might try to justify its attitude by invoking - real or imaginary constitutional obstacles.

And any government genuinely dedicated to the ideal of human rights and fundamental freedoms should not stop at mere formal ratification, but should make every possible effort to contribute to the realisation of this ideal on a universal level. 